\title{
Daily and seasonal limits of time and temperature to activity of degus
}

\author{
Limitaciones diarias y estacionales de tiempo y temperatura sobre la actividad de \\ degus
}

\author{
G.J. KENAGY ${ }^{1}$, ROBERTO F. NESPOLO², RODRIGO A. VÁSQUEZ ${ }^{3}$ \& FRANCISCO BOZINOVIC ${ }^{2}$ \\ ${ }^{1}$ Department of Zoology and Burke Museum, University of Washington, Seattle, Washington 98195, \\ U.S.A.; e-mail: kenagy@u.washington.edu \\ ${ }^{2}$ Centro de Estudios Avanzados en Ecología \& Biodiversidad, Departamento de Ecología, Pontificia \\ Universidad Católica de Chile, CP 651 3677, Santiago, Chile; e-mail: rnespolo@genes.bio.puc.cl; \\ fbozinov@genes.bio.puc.cl \\ ${ }^{3}$ Departamento de Ciencias Ecológicas, Universidad de Chile, Santiago, Chile; \\ e-mail: rvasquez@abello.dic.uchile
}

\begin{abstract}
We present an analysis of behavioral flexibility in a day-active caviomorph rodent, the degu, Octodon degus, in response to temporal (daily and seasonal), spatial, and thermal heterogeneity of its environment. We quantified activity and foraging behavior in a population, together with thermal conditions, in an open habitat in the seasonally hot and arid matorral of central Chile. Summer activity was bimodal, with a gap of more than $8 \mathrm{~h}$ between the morning bout of 2.5 $\mathrm{h}$ of intensive foraging and the afternoon bout of $2 \mathrm{~h}$. More than half of the $4.5 \mathrm{~h}$ of summer activity occurred in the shade of early morning or late afternoon when the sun was below the local skyline. Autumn and spring activity were also bimodal, but with greater proportions of activity under direct solar radiation, and with a shorter midday gap between the two major bouts. Winter activity was unimodal and all occurred under direct solar radiation. In summer, autumn, and spring the activity of degus was curtailed as our index of operative temperature, $\mathrm{T}$, moved above $40{ }^{\circ} \mathrm{C}$. We used a single measurement of $\mathrm{T}_{\mathrm{e}}$ (measured in a thermal mannequin representing degu size, shape and surface properties) as an index of the interactive effects of solar radiation and convection on body temperature. At the winter solstice (June), when degus remained fully exposed to solar radiation throughout the day, $\mathrm{T}_{\mathrm{e}}$ generally remained below $30^{\circ} \mathrm{C}$. Flexibility in the timing of surface activity allows degus to maintain thermal homeostasis and energy balance throughout the year. Degus shift the times of daily onset and end of activity and the number of major bouts (unimodal or bimodal) over the course of the year. They remain active on the surface under a much narrower range or "window" of thermal conditions than those that occur over the entire broad range of the day and year.
\end{abstract}

Key words: Chile, foraging, Octodon degus, seasonality, thermal ecology.

\section{RESUMEN}

Presentamos un análisis de la flexibilidad conductual en la actividad diaria del degu (Octodon degus), un roedor caviomorfo, en respuesta a la heterogeneidad del ambiente temporal (diario y estacional), espacial y térmico. Junto con las condiciones térmicas, cuantificamos la conducta de actividad y forrajeo en una población que vive en un hábitat abierto en el matorral árido y estacional de Chile central. La actividad de verano fue bimodal, con 2,5 h de actividad de forrajeo intenso durante la mañana y con $2 \mathrm{~h}$ durante la tarde. No hubo actividad por mas de $8 \mathrm{~h}$ entre ambos eventos. Más de la mitad de las 4,5 h diarias de actividad de la mañana y de la tarde ocurrieron en la sombra, cuando el sol se encuentra bajo la línea local del cielo. La actividad durante el otoño y la primavera también fue bimodal pero con una mayor proporción de actividad bajo radiación solar directa y con un período de inactividad menor entre los dos eventos principales. La actividad de invierno fue unimodal y bajo radiación solar directa. En verano, otoño y primavera la actividad estuvo sesgada cuando nuestro índice de temperatura operativa, $\mathrm{T}_{\mathrm{e}}$, superó $\operatorname{los} 40^{\circ} \mathrm{C}$. Usamos una medida de $\mathrm{T}_{\mathrm{e}}$ (registrada en un maniquí térmico que representa las propiedades de forma, tamaño y superficie de un degu) como un índice de los efectos interactivos de la radiación solar y la convección sobre la temperatura corporal. Durante el solsticio de invierno (junio), cuando los degus permanecieron todo el día totalmente expuestos al sol, $\mathrm{T}_{\mathrm{e}}$ generalmente permaneció bajo $30^{\circ} \mathrm{C}$. La flexibilidad en el tiempo de la actividad superficial le permitió a los degus mantener su homeostasis térmica y balance de energía anual. Los degus cambiaron sus períodos de inicio y término así como el número de eventos de actividad (unimodal o bimodal) durante el año. Estos roedores permanecieron activos en la superficie bajo un rango mucho más estrecho de condiciones térmicas que las que ocurren durante el largo del día y año.

Palabras clave: Chile, forrajeo, Octodon degus, estacionalidad, ecología térmica. 


\section{INTRODUCTION}

How an animal uses its habitat and the resulting daily behavioral rhythms may undergo dynamic changes over daily and annual time scales due to temporal variation in the opportunities and limits of the environment. Options of what to do are time-dependent, and the "decisions" (elected behaviors) of the animal are integrated responses to the environment and the animal's internal state, e.g., energy balance (Krebs \& Kacelnik 1991, Cuthill \& Houston 1997, Houston \& McNamara 1999, Clark \& Mangel 2000). Temperature is a fundamental environmental feature, and spatiotemporal variation of environmental temperature clearly can set limits to activity by challenging the thermal homeostasis of animals (Gates 1980). We present here an investigation in physiological and behavioral ecology that seeks to shed light on temporal and spatial use of habitat with particular regard to thermal environmental conditions (Huey 1991).

We selected the degu (Octodon degus) for an empirical field study of daytime activity that addresses these issues of time (both daily and seasonal scales), temperature, and behavioral response to habitat. Degus (adult mass $\sim 160-200 \mathrm{~g}$ ) are common herbivorous caviomorph rodents in the central Chilean matorral, which is hot and dry in summer and cool and moist in winter (Rundel 1981). As the only endemic small mammals of central Chile that are routinely active in the daytime, their conspicuous diurnal activity attracted the attention of the Italian naturalist Molina (1782), who mistakenly identified them as squirrels. Their general activity, reliance on shrub cover as a refuge from heat and predators, and thermal response to heat loads have been described by Fulk (1976), Yáñez \& Jaksic (1978), Iriarte et al. (1989), and Lagos et al. (1995), though these previous studies did not assess seasonality. Degus are generally associated with shrub cover and variable amounts of open space in which they forage (Le Boulengé \& Fuentes 1978, Jaksic et al. 1981a, Meserve et al. 1984, Iriarte et al. 1989).

We designed our study to test how degus adjust their activity on daily and seasonal time scales in relation to prevailing thermal conditions. To focus this basic question on the movement of degus between the surface and their burrows, we selected open habitat where the major shade cover of trees, shrubs, and smaller woody perennial vegetation was not available. Investigating the general hypothesis that temporal and spatial variation in thermal conditions limits the election of surface activity, our most general prediction was that degus adjust the beginning and end of periods of above-ground activity seasonally in accord with the suitability of thermal conditions. Does summer daytime heat prohibit activity? Do cold winter conditions restrict activity? Because Octodon degus belongs to a rodent family (Octodontidae) that is otherwise generally nocturnal (Contreras et al. 1987), our study also raises the question whether the daytime activity of degus has resulted in any specialized thermal tolerance.

\section{MATERIAL AND METHODS}

The study was conducted about $30 \mathrm{~km}$ west of Santiago, at a remote site on a property of the Facultad de Agronomía, Universidad de Chile, in Quebrada de La Plata, at $33^{\circ} 29^{\prime} \mathrm{S}, 70^{\circ} 56^{\prime} \mathrm{W}$ at elevation $800 \mathrm{~m}$. The general habitat was typical of central Chilean matorral, but we selected our particular study area because of its extensive open space and sparse shrub and tree cover. The area was dotted with numerous degu burrows, and runways radiated from burrow entrances through an extensive grass and herb cover. Most of the nearby shrubs were Trevoa trinervis (deciduous), but Baccharis linearis (evergreen) was also present. A few small trees were also spread through the nearby area, mainly Acacia caven and Quillaja saponaria, both of which are evergreen in this area.

A 2.6-ha area, laid out as a $10 \times 14$ grid of 140 staked locations at $15-\mathrm{m}$ intervals, was used for regular trapping of the degu population, some of which was for other studies. We assessed percent cover by shrubs and trees in each $15 \times 15 \mathrm{~m}$ square of the grid by counting the shrubs and trees and then estimating, to the nearest $10 \%$, the percentage of surface covered by shrubs and trees combined. We set live traps (mostly Sherman aluminum box traps; smaller numbers of Tomahawk wire traps), baited with oats, to assess numbers of degus that could be captured in day versus night. We set traps overnight as follows: in 1996; 150 traps on 21-22 November, 189 on 12-13 December; in 1997: 197 traps on 26-27 March, 40 on $27-$ 28 June, 40 on 12-13 September, 150 on 17-18 September, 150 on 18-19 September, and 150 on 19-20 September. We timed the trapping carefully to open and bait traps $30 \mathrm{~min}( \pm 10 \mathrm{~min})$ after sunset on the horizon and to close them $30 \mathrm{~min}( \pm$ $10 \mathrm{~min}$ ) before sunrise on the horizon. Our daytime trapping involved the same numbers and dates.

To quantify population levels of activity we observed and visually counted degus in a small 
part of the large grid that contained six areas that could be recognized using the grid stakes and were clearly seen from our elevated observation point on the east edge of the grid. This entire observation area was open and visible, with extensive grass and herb cover (90-100\%), in which the animals foraged. In December 1996 we initially observed only four small areas, which totaled about 0.18 ha. Due to a decline in population density we expanded the total area of observation from March 1997 onward to include two additional areas, making a total of 0.83 ha. The successive decrease in animals observed at each season (Fig. 1-4) was due to a general population decline.

We obtained continuous all-day counts of activity on four dates near the solstices and equinoxes: 10 December 1996 and 24 March, 10 June, and 13 September 1997. Thereby we examined the broad variation in daily activity over the course of the year. We suspected that day-to-day variation was very low compared to annual variation for several reasons. Skies are typically clear in this area, and thus both the daylight and daily thermal profile show little day-to-day change. We avoided making observations on any day that had significant cloud cover. In other work in the area we observed a strong short-term consistency of activity from day to day. Our complete and continuous observation throughout the chosen days produced daily patterns that differed conspicuously over the year. Two of us generally observed together, using binoculars, from before sunrise until after sunset, and each counted degus in a share of the four or six small areas; during midday in summer and autumn when activity was low or nonexistent only one of us remained on watch. We scanned the target areas on an ongoing basis to remain aware of the comings and goings of individuals. However, our counts were made strictly within the first minute of each five-minute interval by recording the number of degus actually seen at that time. We averaged the six values obtained over each half hour to give degus active each half hour (Fig. 1-4). All clock times are Chilean Standard Time, i.e., in December and March we subtracted one hour from local daylight savings time.

We assessed activity, as described elsewhere (Kenagy et al. 2002), at each of the one-minute counts according to four categories: (1) sitting (stationary, lack of locomotion, alert and vigilant, performing small motor functions such as grooming); (2) walking (often while searching for and gathering food); (3) running (rapid movement, usually within runways, and for longer distances); (4) foraging (searching for, harvest- ing, or ingesting food). Foraging (4) can occur simultaneously, by definition, with states (1) or (2) but not (3), whereas categories (1), (2), and (3) are mutually exclusive. For foraging we also estimated the proportion of all animals foraging. In the earliest and latest activity none of the few animals present was foraging; later typically 75 to $100 \%$ of all individuals were typically foraging. We designated two levels of foraging intensity in Fig. 1-4: (i) a high level when most (75$100 \%$ ) animals were foraging, and (ii) a low level, when less than one-third of all animals was foraging, or if only one animal was present.

We applied a limited version of the concept of operative environmental temperature, $\mathrm{T}_{\mathrm{e}}$ (Bennett et al. 1984, Bakken 1992). $\mathrm{T}_{\mathrm{e}}$ is an equilibrium temperature, measured with a physical model of an animal that lacks physiology and behavior. The temperature achieved by the model is due to its physical properties (size, shape, color, surface covering) in response to the action of solar radiation, wind, and related environmental parameters. Although calibration of thermal models (using an artificial internal heat flux), replication of measurements, and further calculations are necessary to predict body temperature (Walsberg \& Wolf 1996, Bakken et al. 1999), we used $\mathrm{T}_{\mathrm{e}}$ as a simple uncalibrated index as originally applied by Bennett et al. (1984). This simple application cannot be used to predict the physiological responses of a live animal (Walsberg \& Wolf 1996). Our application thus amounts to use of a single standardized measurement of $\mathrm{T}_{\mathrm{e}}$ to correlate with changes of behavior. Despite the lack of dynamic physiology and the problems of calibration and replication, $\mathrm{T}_{\mathrm{e}}$ has a greater range and is thus more sensitive and potentially more relevant to the thermal exposure of an animal than the simple measurement of shaded air temperature, $\mathrm{T}_{\text {air }}$.

We recorded micrometeorological data, usually at 15-min intervals throughout the observations (Fig. 1-4). Shaded air temperatures $\left(\mathrm{T}_{\text {air }}\right)$ at $5 \mathrm{~cm}$ (degu height) and $2 \mathrm{~m}$ were obtained with copper-constantan thermocouples at a station within the observation area, as read from a Sensortek telethermometer at our observation point. $T_{e}$ was recorded at the same station from a thermocouple permanently secured inside the hollow mounted skin of a degu, i.e., a "thermal mannequin" (Chappell \& Bartholomew 1981a, Bennett et al. 1984). The mannequin, prepared in the typical quadrupedal posture, had a nose-rump length of $195 \mathrm{~mm}$ and a mid-body girth of 175 $\mathrm{mm}$; we mounted the skin over a wire frame covered with aluminum foil, after the methods of Bennett et al. (1984). To standardize and maximize the influence of solar load on $\mathrm{T}_{\mathrm{e}}$, we used a 


\section{SUMMER}
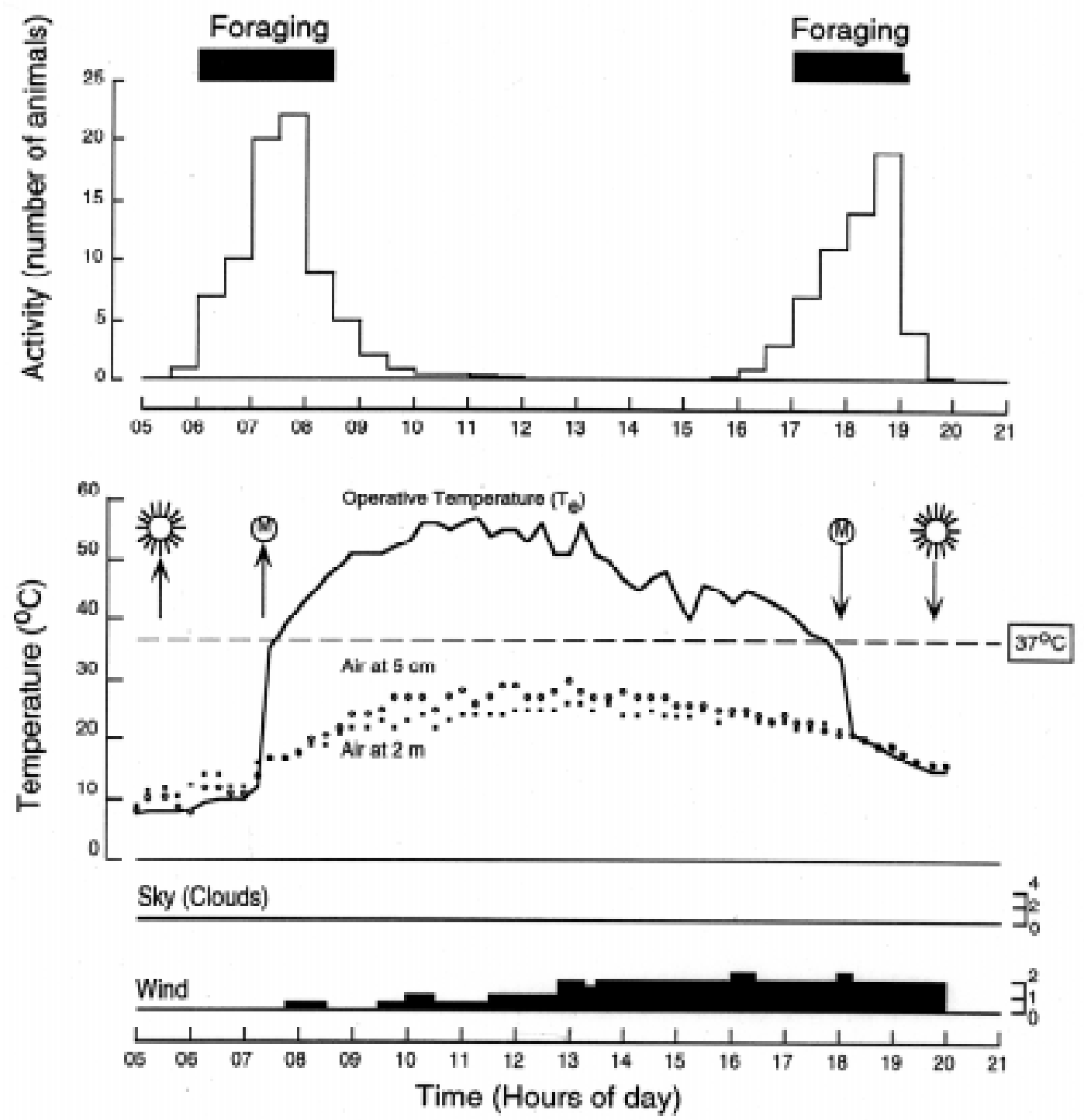

Fig. 1: Population activity and foraging by degus in relation to time of day (Chilean Standard Time) and physical environmental conditions on 10 December 1996, near the summer solstice. Activity is plotted over half-hour intervals, showing the average number of degus observed every five minutes during one minute of counting over an area of 0.18 ha; see Methods for details and explanation of intensity of "Foraging". Operative environmental temperature $\left(\mathrm{T}_{\mathrm{e}}\right)$ is that of a thermal mannequin (see Methods); other temperatures are those of air at $5 \mathrm{~cm}$ (degu height) and $2 \mathrm{~m}$ above the ground. The dashed line at $37^{\circ} \mathrm{C}$ represents normal body temperature of degus. Solar symbols represent civil sunrise and sunset $\left(0^{\circ}\right.$ horizon) and the $\mathrm{M}$ symbol represents the time when direct solar radiation first struck the mannequin in the morning and last impinged on it in the afternoon. Sky $(0=$ cloudless; $2=$ light, partial cover; $4=$ heavy overcast $)$ and wind $(0=$ none; 2 heavy) are relative scales, described in Methods.

Actividad poblacional y de forrajeo de degus en relación a las horas del día (Tiempo Chileno Estándar) y a las condiciones físicas del ambiente el 10 de diciembre de 1996, cerca del solsticio de verano. La actividad se grafica en intervalos de media hora mostrando el número promedio de degus observados cada cinco minutos y durante un minuto de conteo en un área de 0,18 ha; véase Métodos para detalles y explicaciones de la intensidad de "Forrajeo". La temperatura operativa ( $\mathrm{T}_{\mathrm{e}}$ ) es la del maniquí térmico (véase Métodos); las otras temperaturas son del aire a $5 \mathrm{~cm}$ (altura de un degu) y $2 \mathrm{~m}$ sobre el suelo. La línea segmentada a $37^{\circ} \mathrm{C}$ representa la temperatura corporal normal de los degus. Los símbolos del sol representan el amanecer y atardecer civil $\left(0^{\circ}\right.$ de horizonte) y el símbolo $\mathrm{M}$ representa el momento del día en que el maniquí recibe o deja de recibir radiación solar directa. Cielo $(0=$ despejado; $2=$ con pocas nubes; $4=$ completamente cubierto $)$ y viento $(0=$ nada; $2=$ mucho $)$. Ambas escalas relativas se describen en Métodos. 



Fig. 2: Population activity and foraging by degus in relation to time of day (Chilean Standard Time) and physical environmental conditions on 24 March 1997, near the autumnal equinox. Activity is plotted over half-hour intervals, showing the average number of degus observed every five minutes during one minute of counting over an area of 0.83 ha. The size of the observation area was increased over that used for the data of Fig. 1 to accommodate for the observed decrease in population density (see Methods); for clarity of relative hour-by-hour changes in activity, the Y-axis is adjusted accordingly in Fig. 2-4. Other explanations as in Fig. 1.

Actividad poblacional y de forrajeo de degus en relación a las horas del día (Tiempo Chileno Estándar) y a las condiciones físicas del ambiente el 24 de marzo de 1997, cerca del equinoccio de otoño. La actividad se grafica en intervalos de media hora mostrando el número promedio de degus observados cada cinco minutos y durante un minuto de conteo en un área de 0,83 ha. El tamaño del área de observación fue aumentado en relación a lo de los datos de la Fig. 1 para acomodar a la disminución observada en densidad de población (véase Metodos); para efectos de claridad de cambios en la actividad relativa de una hora a la otra, el eje Y fue ajustado en las Fig. 2-4. Mayores en la Fig. 1. 
single mannequin in a fully open location, reorienting it occasionally to maintain perpendicularity to solar radiation.

We recorded level of cloud cover every $15 \mathrm{~min}$ on a scale of 0 (cloudless) to 4 (heavy overcast), but we avoided collecting activity data on any day when cloud cover would have reached levels 3 or 4. We estimated wind speed on a scale of 0 (no apparent movement) to 2 (maximum), corresponding to speeds of 0 to $4 \mathrm{~m} \mathrm{~s}^{-1}$ measured with a handheld anemometer.
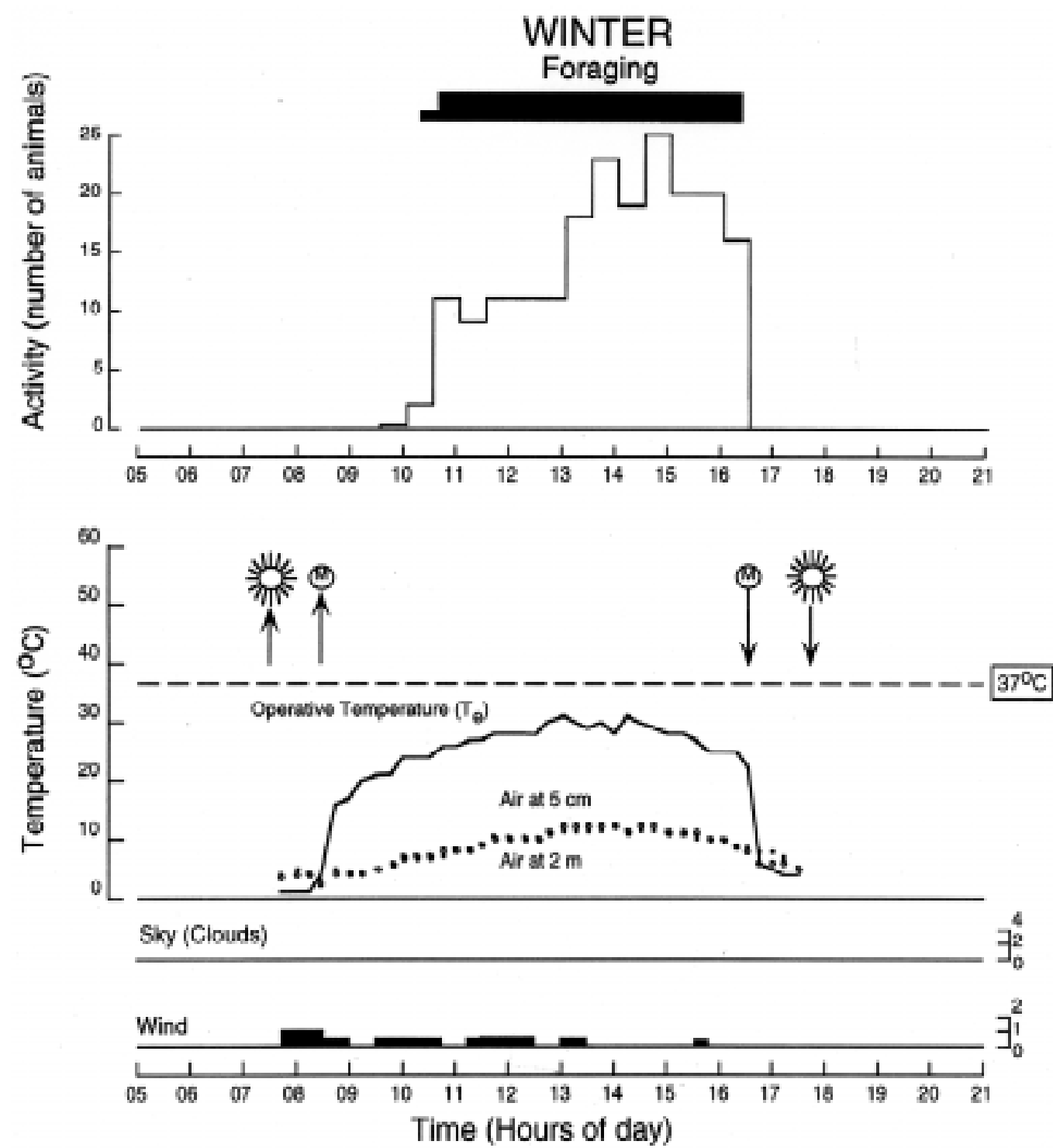

Fig. 3: Population activity and foraging by degus in relation to time of day (Chilean Standard Time) and physical environmental conditions on 10 June 1997, near the winter solstice. Activity is plotted over half-hour intervals, showing the average number of degus observed every five minutes during one minute of counting over an area of 0.83 ha. The size of the observation area was increased over that used for the data of Fig. 1 to accommodate for the observed decrease in population density (see Methods); for clarity of relative hour-by-hour changes in activity, the y-axis is adjusted accordingly in Fig. 2-4. Other explanations as in Fig. 1.

Actividad poblacional y de forrajeo de degus en relación a las horas del día (Tiempo Chileno Estándar) y a las condiciones físicas del ambiente el 10 de junio de 1997, cerca del solsticio de invierno. La actividad se grafica en intervalos de media hora mostrando el número promedio de degus observados cada cinco minutos y durante un minuto de conteo en un área de 0,83 ha. El tamaño del área de observación fue aumentado en relación a lo de los datos de la Fig. 1 para acomodar a la disminución observada en densidad de población (véase Metodos); para efectos de claridad de cambios en la actividad relativa de una hora a la otra, el eje Y fue ajustado en las Fig. 2-4. Mayores en la Fig. 1. 
To characterize the general thermal seasonality of the area, we obtained long-term $\mathrm{T}_{\mathrm{a}}$ data from the Pudahuel weather station of the Chilean Meteorological Service (http://www.meteochile.cl), about $10 \mathrm{~km}$ from the study site. We averaged monthly records of mean maximum and minimum over 19 years (1979-1997) (Fig. 5).

\section{RESULTS}

\section{Activity, time, and temperature}

At all times of year degus began foraging shortly after they emerged from their burrows into open habitat in the morning. Within the defined observation areas, about $75 \%$ of the grid squares completely lacked shrub and tree cover, and the remaining grid squares had less than $30 \%$ cover. We present our observations one season at a time (Fig. 1-4) and then the overall pattern (Fig. 5).

Summer.- Near the summer solstice (December) the first degu emerged onto the surface at $05: 45 \mathrm{~h}$, about $20 \mathrm{~min}$ after sunrise on the unobstructed horizon and $1.5 \mathrm{~h}$ before the sun first impinged on the study site (Fig. 1). Within $15 \mathrm{~min}$ many other animals emerged and were foraging. Extensive foraging and activity continued for only $2.5 \mathrm{~h}$, until 08:30 h. After that only a few degus were seen, resting and mostly in shaded burrow openings or in the shadows of small rocks. We sighted a few individuals over the next three hours, none was foraging, and they appeared only briefly to run between burrows. After 12:00 h we saw no degus until 15:55 h, when one animal emerged briefly, sitting in the shaded mouth of its burrow. A few others appeared briefly over the next hour, sitting in shaded spots by rocks or in burrow mouths. By 17:00 h degus moved out into the open and foraged, which lasted only two hours, until 19:00 h, about $45 \mathrm{~min}$ before sunset on the horizon. The few degus seen from 19:00-19:30 h sat or moved briefly, but did not forage.

Summer morning activity began when $\mathrm{T}_{\mathrm{e}}$ and $\mathrm{T}_{\text {air }}$ were about $10{ }^{\circ} \mathrm{C}$ and the sun was not yet above the local skyline (Fig. 1). Half way through morning foraging $\mathrm{T}_{\mathrm{e}}$ reached $40{ }^{\circ} \mathrm{C}$ and then climbed to $47^{\circ} \mathrm{C}$ by $08: 30 \mathrm{~h}$, when foraging ceased all together. The difference between sunrise or sunset on the local horizon $\left(0^{\circ}\right)$ and the presence of sun on the observation site was due to the profile of hills on the local skyline. In contrast to the higher values of $\mathrm{T}_{\mathrm{e}}$, shaded air temperatures remained near $20^{\circ} \mathrm{C}$ during morning activity. The second bout of activity began in late afternoon at 17:00 $\mathrm{h}$ as $\mathrm{T}_{\mathrm{e}}$ dropped to $40{ }^{\circ} \mathrm{C}$; direct solar radiation ceased $1 \mathrm{~h}$ later, at 18:00 h, when the sun dropped below the skyline, and thus the last full hour of foraging, until 19:00 h, occurred in shade. The afternoon increase of winds contributed to the decline of $\mathrm{T}_{\mathrm{e}}$ starting at 13:00 $\mathrm{h}$ (Fig. 1). The association of the end of morning foraging with $\mathrm{T}_{\mathrm{e}}$ rising above $40{ }^{\circ} \mathrm{C}$ and the beginning of afternoon foraging associated with $\mathrm{T}_{\mathrm{e}}$ falling below 40 ${ }^{\circ} \mathrm{C}$ suggests that surface activity is inhibited by the high environmental heat loads associated with summertime solar radiation.

Autumn.- At the autumnal equinox (March) the first degu emerged about 07:30 h, about 40 min after sunrise at the horizon and $30 \mathrm{~min}$ before the sun struck the observation site (Fig. 2). Intense population foraging lasted $2.7 \mathrm{~h}$ in the morning. Most of the few animals seen from 10:30 h until about 15:00 h were resting in the shade of mouths of burrows or running quickly between burrows. After 15:00 h many animals emerged from burrows and by $15: 10 \mathrm{~h}$ foraging was intensive and continued until 17:35 h, amounting to a 2.7-h foraging period (Fig. 2). The last animal was seen at 18:05 h, $35 \mathrm{~min}$ after solar radiation left the observation site and $45 \mathrm{~min}$ before sunset on the horizon.

Autumnal activity and foraging began in the morning at a $\mathrm{T}_{\mathrm{e}}$ of about $10^{\circ} \mathrm{C}$, and this rose to near $40^{\circ} \mathrm{C}$ by the middle of the period and climbed to $40-45^{\circ} \mathrm{C}$ in the last hour of morning foraging (Fig. 2). Very light clouds were present most of the day, but thinning of clouds around noon provided the maximum $\mathrm{T}_{\mathrm{e}}$, just greater than $50^{\circ} \mathrm{C}$. Intensive activity and foraging did not resume until $\mathrm{T}_{\mathrm{e}}$ dropped below $40^{\circ} \mathrm{C}$ after 15:00 h. Light afternoon cloud cover in the west enhanced the decline of $\mathrm{T}_{\mathrm{e}}$ along with afternoon winds. A transient effect of clouds blocking sun was responsible for the sharp decline in $\mathrm{T}_{\mathrm{e}}$ between 15:00 and 16:00 $\mathrm{h}$, and this was accompanied by intense foraging activity. Conversely, when the clouds moved and allowed penetration of unobstructed solar radiation at 16:00 $\mathrm{h}, \mathrm{T}_{\mathrm{e}}$ rose sharply and foraging declined slightly. The entire afternoon foraging occurred with sun striking the observation area, and $\mathrm{T}_{\mathrm{e}}$ dropped from around 35 to about $20{ }^{\circ} \mathrm{C}$ over the last half hour of foraging.

Winter.- At the winter solstice (June) a single degu emerged from its burrow just after 09:30 h, but significant activity and foraging did not begin until 10:30 h, about $2.75 \mathrm{~h}$ after sunrise at the horizon and $2 \mathrm{~h}$ after the first direct solar radiation struck the area (Fig. 3). Population activity and foraging in winter were strictly unimodal. Though essentially all active degus were foraging in late morning, the intensity of population activity nearly doubled by the afternoon (Fig. 3). General activity and foraging dropped precipitously 
when direct solar radiation left the study area, at $16: 32 \mathrm{~h}$, about $1.25 \mathrm{~h}$ before sunset on the horizon (Fig. 3). The single winter foraging period amounted to $5.8 \mathrm{~h}$.

All winter activity occurred while sun was shining on the degus (Fig. 3). Activity onset was phased much later with respect to sunrise than in summer and autumn, which allowed $\mathrm{T}_{\mathrm{e}}$ to exceed $25^{\circ} \mathrm{C}$ by the time of most foraging activity, despite a shaded air temperature that remained about $10 \pm 2{ }^{\circ} \mathrm{C}$. Even in the afternoon and when the wind ceased, the highest $\mathrm{T}_{e}$ was only $31{ }^{\circ} \mathrm{C}$ (Fig. 3 ). The entire day's activity thus occurred in open sun with $\mathrm{T}_{\mathrm{e}}$ remaining $<31{ }^{\circ} \mathrm{C}$, and degu activity did not appear limited by the maximum environmental heat loads of winter.

\section{SPRING}
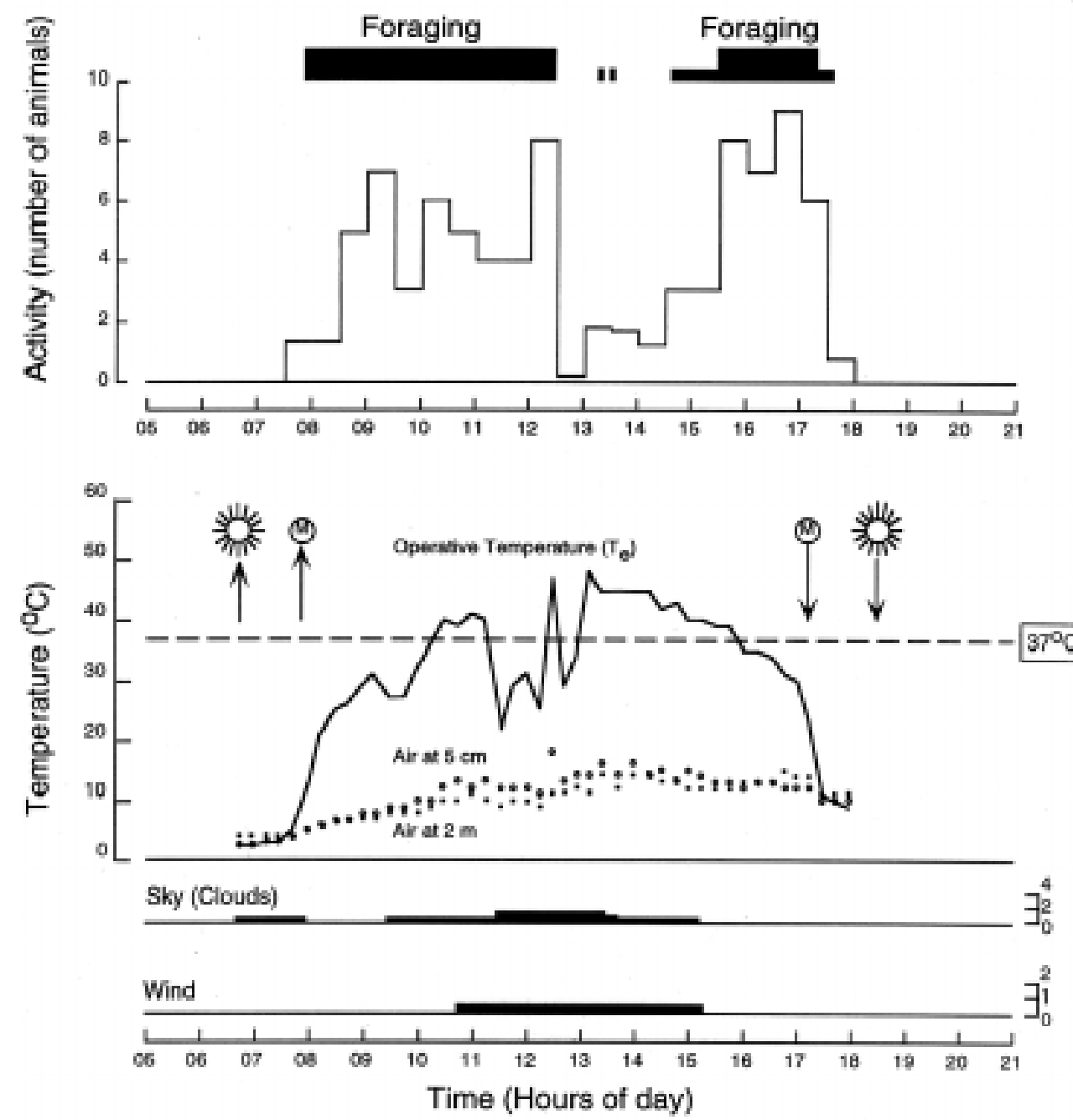

Fig. 4: Population activity and foraging by degus in relation to time of day (Chilean Standard Time) and physical environmental conditions on 13 September 1997, near the spring equinox. Activity is plotted over half-hour intervals, showing the average number of degus observed every five minutes during one minute of counting over an area of $0.83 \mathrm{ha}$. The size of the observation area was increased over that used for the data of Fig. 1 to accommodate for the observed decrease in population density (see Methods); for clarity of relative hour-by-hour changes in activity, the $\mathrm{Y}$-axis is adjusted accordingly in Fig. 2-4. Other explanations as in Fig. 1.

Actividad poblacional y de forrajeo de degus en relación a las horas del día (Tiempo Chileno Estándar) y a las condiciones físicas del ambiente el 13 de septiembre de 1997, cerca del equinoccio de primavera. La actividad se grafica en intervalos de media hora mostrando el número promedio de degus observados cada cinco minutos y durante un minuto de conteo en un área de 0,83 ha. El tamaño del área de observación fue aumentado en relación a lo de los datos de la Fig. 1 para acomodar a la disminución observada en densidad de población (véase Metodos); para efectos de claridad de cambios en la actividad relativa de una hora a la otra, el eje Y fue ajustado en las Fig. 2-4. Mayores en la Fig. 1. 
Spring.- At the vernal equinox (September) activity returned to a bimodal pattern (Fig. 4). The first degu emerged at 07:40 h, about an hour after sunrise and only 15 min before direct solar radiation impinged, and other members of the population became active within $10 \mathrm{~min}$ (Fig. 4). Activity declined precipitously after $12: 30 \mathrm{~h}$, and morning foraging amounted to $4.6 \mathrm{~h}$. Over the next $3 \mathrm{~h}(12: 30$ to $15: 30 \mathrm{~h})$ few animals appeared, showing only brief movements and occasional foraging. From 15:25 until 17:15 h the population resumed intensive foraging, for $1.8 \mathrm{~h}$, after which direct solar radiation ceased, about $1.15 \mathrm{~h}$ before sunset (Fig. 4).

At the beginning of early morning activity degus encountered an initial $\mathrm{T}_{\mathrm{e}}$ and $\mathrm{T}_{\text {air }}$ of only $5{ }^{\circ} \mathrm{C}$ (Fig. 4). $T_{e}$ rose during the morning, but still did not reach $40{ }^{\circ} \mathrm{C}$ until midway through foraging, when it held for about an hour and then declined as a modest cloud cover and light wind developed (Fig. 4). Morning foraging ended when $T_{e}$ rose above $45^{\circ} \mathrm{C}$. Afternoon foraging essentially all occurred at $\mathrm{T}_{\mathrm{e}}<40^{\circ} \mathrm{C}$, and intense activity stopped with a precipitous drop in $\mathrm{T}_{\mathrm{e}}$ below $10^{\circ} \mathrm{C}$.

Upper thermal limit to surface activity. - In summer, autumn, and spring (but not winter), when $\mathrm{T}_{\mathrm{e}}$ rose above $40^{\circ} \mathrm{C}$, activity was curtailed (Fig. 1, 2 , and 4), and from the year-round summation of population foraging only $12 \%$ of all degu activity occurred when $\mathrm{T}_{\mathrm{e}}$ exceeded $40{ }^{\circ} \mathrm{C}$ (Table 1 ). The overall annual thermal range for activity fell between $\mathrm{T}_{\mathrm{e}}=5-50^{\circ} \mathrm{C}$, and the breadth and distribu- tion of temperatures within this range varied widely according to season (Table 1). In winter $85 \%$ of the activity fell within a single 5-degree range (25$30{ }^{\circ} \mathrm{C}$ ) that generally lies within the thermal neutral zone $\left(24-32{ }^{\circ} \mathrm{C}\right.$, Rosenmann 1977). On the other hand, in summer $85 \%$ of the activity occurred over a 35 -degree range $\left(10-45^{\circ} \mathrm{C}\right)$ and was distributed bimodally toward the extremes of this range (Table 1). The occurrence of virtually all winter activity within the range of thermal neutrality resulted from the low intensity of winter solar radiation (reflected by lower values of $\mathrm{T}_{\mathrm{e}}$ ) and a period of activity that occurred $100 \%$ within the hours of directly impinging solar radiation (Table 2 ). In contrast, summer activity was only about half under sun and the other half protected by early morning and late afternoon skyline shade (Table 2). This bimodal distribution of $\mathrm{T}_{\mathrm{e}}$ 's was below thermal neutrality during the shaded portion of activity and above thermal neutrality during the sun-exposed portion (Table 1). This summer environmental bimodality resulted from the fact that the thermally neutral range of $\mathrm{T}_{\mathrm{e}}$ (24-32 ${ }^{\circ} \mathrm{C}$ ), which afforded comfortable existence throughout the active day in winter, was rapidly crossed once in the morning and once in the afternoon in summer (Fig. 1). The pattern we observed in autumn likewise showed little time available in the thermally neutral range of $\mathrm{T}_{\mathrm{e}}$ (Fig. 2, cf. Table 1), whereas the spring pattern showed greater time availability in thermal neutrality (Fig. 4, cf. Table 1).

TABLE 1

Seasonal summary of degu population foraging activity in relation to operative temperature, $\mathrm{T}_{\mathrm{e}}$. Data are point observations obtained during one continuous all-day count of activity per season, near the solstices and equinoxes

Resumen estacional de la actividad de forrajeo poblacional de degus en relación a la temperatura operativa, $\mathrm{T}_{\mathrm{e}}$. Los datos corresponden a observaciones puntuales de registro continuo de actividad realizadas durante un día en cada estación, cercanos a los correspondientes solsticios y equinoccios

\begin{tabular}{lcccccccccc}
\hline & \multicolumn{7}{c}{ Operative temperature (intervals of 5 ${ }^{\circ} \mathrm{C}$ ) } \\
& $5-10$ & $10-15$ & $15-20$ & $20-25$ & $25-30$ & $30-35$ & $35-40$ & $40-45$ & $45-50$ & 8 \\
Summer & 6 & 11 & 6 & 5 & 1 & 1 & 14 & 2 \\
Autumn & 2 & 4 & 7 & 1 & 2 & 11 & 18 & 11 & 5 \\
Winter & & & & & 6 & 60 & 3 & & 18 & 5 \\
Spring & 2 & 1 & 2 & 9 & 25 & 15 & 18 \\
\hline
\end{tabular}

Values are the numbers of 5-min intervals during population foraging activity in which $\mathrm{T}_{\mathrm{e}}$ fell within each $5{ }^{\circ} \mathrm{C}$ range, from data contained in Fig. 1-4. The underlined range of $\mathrm{T}_{\mathrm{e}}$ for each season represents the range that includes approximately 85 $\%$ of all activity. Total 5 -min intervals are 261, consisting of 54 in summer, 61 in autumn, 69 in winter, and 77 in spring. The sum of 31 intervals within the range of $40-50{ }^{\circ} \mathrm{C}$ amounts to $12 \%$ of all activity. 
The benefit of bimodal activity patterns, whether in summer, autumn, or spring, was avoidance of midday thermal extremes. However, the cost of avoiding the midday extremes was the paradoxical exposure at each of these seasons to morning thermal conditions that were colder than any experienced by the degus in winter (Table 1).

Nocturnal activity?- Because the possibility of nocturnal activity by Octodon degus has been raised, we conducted special nocturnal trapping to ascertain any night-time surface activity. We captured no degus on any of the following nights of trapping: 1996: 21-22 November, 12-13 December; 1997: 26-27 March, 27-28 June, 12-13 September, 17-18 September, 18-19 September, and 19-20 September. With the same traps set during the following mornings, we captured the following numbers of degus in normal daylight hours: 1996: 29 on 20 November, 17 on 9 December, 54 on 13 December; 1997: 14 on 22 March, 17 on 27 May, 25 on 31 May, 26 on 2 June, 1 on 18 September, 2 on 19 September, and 2 on 20 September. We conclude that degus were not active at night at any time of year.

\section{FORAGING ACTIVITY}

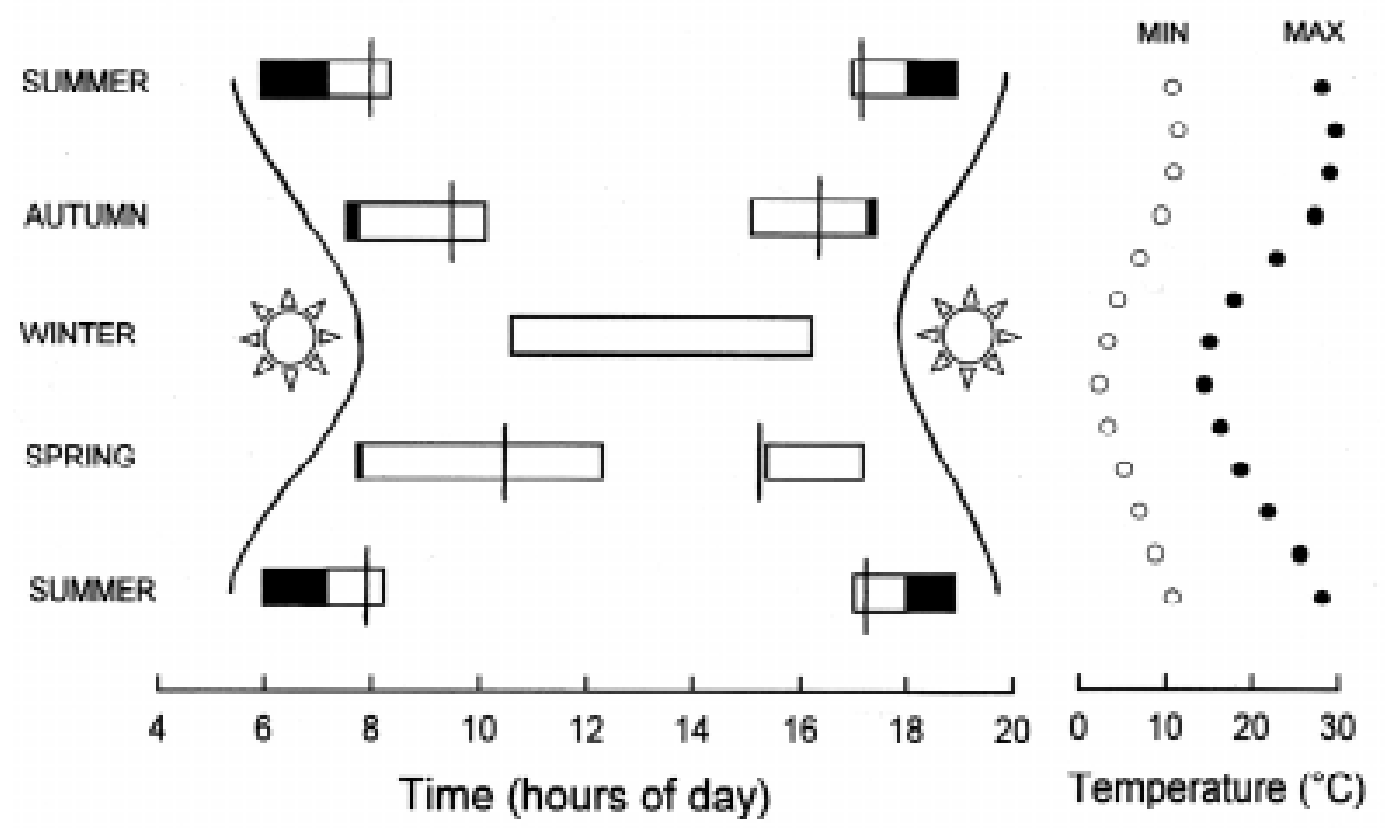

Fig. 5: Summary of daily foraging activity of degus with respect to seasonal changes in day length and temperature. Horizontal bars represent the daily periods of intense foraging activity by the population, as shown in Fig. 1-4. The shaded portion of the bars represents activity that occurred before direct solar radiation impinged on the observation site in the morning or after direct solar radiation ceased in the afternoon (cf. Fig. 1-4, M-arrows indicating sun on/off the mannequin). The clear portion of the bars represents activity that occurred under direct solar radiation, and the longer vertical lines across the bar represents the first (A.M.) and last (P.M.) time when $\mathrm{T}_{\mathrm{e}}$ was $40^{\circ} \mathrm{C}$. The continuous vertical lines indicate sunrise (left) and sunset (right) with respect to the unobstructed $\left(0^{\circ}\right)$ horizon. Time is Chilean Standard Time. Summer $=$ December, Autumn $=$ March, etc., as in Fig. 1-4, with Summer repeated at bottom. Large dots at right are long-term monthly means of maximum and minimum $\mathrm{T}_{\text {air }}$ at a weather station near the study site (see Methods); months of January and February are plotted between Summer and Autumn, April, May between Autumn and Winter, etc.

Resumen de la actividad de forrajeo diaria de degus en función de los cambios estacionales en el largo del día y en la temperatura. Las barras horizontales representan los períodos diarios de intensa actividad de forrajeo de la población (Fig. 1-4). La proporción sombreada de las barras representa la actividad que ocurre antes que la radiación solar llegue al sitio de observación en la mañana y despues que la radiación solar cesa en la tarde (cf. Fig. 1-4. Las flechas -M indican si sol esta sobre el maniquí o no). La proporción clara de las barras representa la actividad que ocurrió bajo radiación solar directa, y las líneas verticales largas a través de las barras representan el tiempo inicial (A.M) y final (P.M.) cuando $\mathrm{T}_{\mathrm{e}}$ fue $40{ }^{\circ} \mathrm{C}$. Las líneas verticales continuas indican amanecer (izquierda) y atardecer (derecha) con respecto al horizon sin obstrucción $\left(0^{\circ}\right)$. El tiempo es Tiempo Chileno Estándar. Verano = diciembre, Otoño = marzo, etc como en las Fig. 1-4, con el verano repetido abajo. Los puntos grandes de la derecha representan las medias mensuales de temperaturas mínimas y máximas de la temperatura del aire de una estación meteorológica cercana al sitio de estudio (véase Métodos); los meses de enero, febrero se grafican entre verano y otoño; abril, mayo entre otoño e invierno, etc. 


\section{Seasonality of environment and degu activity}

Associated with seasonal variation in day length and temperatures we detected conspicuous seasonal changes in timing of daily activity of degus. Day length (sunrise to sunset on the $0^{\circ}$ horizon) ranged from about $14 \mathrm{~h}$ in summer to $10 \mathrm{~h}$ in winter (Fig. 5). The time from earliest to latest major activity ("photoperiodic" exposure) ranged from $13 \mathrm{~h}$ in summer down to only $5.8 \mathrm{~h}$ in winter. This means that winter animals remained in their burrows for about $18 \mathrm{~h}$ per day. Autumn and spring photoperiodic exposures were, respectively, 9.9 and $9.5 \mathrm{~h}$. The total daily amount of time actually spent on the surface by the population was fairly similar over the course of the year (Table 2), when compared to the extreme range of 13 to $5.8 \mathrm{~h}$ in time from first to last activity.

Throughout the year activity always fell between sunrise and sunset on the $0^{\circ}$ horizon (Fig. $5)$. Furthermore, in winter all activity occurred when sun was shining directly on the animals, and most of the activity in autumn and spring also occurred with sun above the skyline (Fig. 5, cf. Table 2). However, in summer more than half of the activity occurred either in the morning after sunrise at the $0^{\circ}$ horizon but before the sun struck the observation area, or in the afternoon between solar disappearance below the skyline and sunset at the $0^{\circ}$ horizon (Fig. 5, see shaded portions of bars in summer; cf. Table 2). Degus in summer thus spent less time exposed to direct solar radiation than at any other season (Table 2), and local skyline topography played a significant role in providing the shade that allowed degus to avoid summer solar flux.

Monthly means of daily maximum $\mathrm{T}_{\text {air }}$ showed an annual range of $16{ }^{\circ} \mathrm{C}$ while those of minima ranged $9{ }^{\circ} \mathrm{C}$ (Fig. 5). $\mathrm{T}_{\mathrm{e}}$ was higher than daytime $\mathrm{T}_{\text {air }}$ and more relevant to the thermal limits of degus with respect to solar influx. In summer $\mathrm{T}_{\mathrm{e}}$ remained above $T_{b}$ when direct solar radiation impinged on the area (Fig. 1). In autumn and spring $\mathrm{T}_{\mathrm{e}}$ alternated closely above and below $\mathrm{T}_{\mathrm{b}}$ (Fig. 2 and 4), and in winter $\mathrm{T}_{\mathrm{e}}$ remained below $\mathrm{T}_{\mathrm{b}}$ all day (Fig. 3).

Seasonal biotic variation also contributed to changes in daily time and energy balance of degus. Juveniles emerged in spring (October) and continued their postnatal growth as they fed on fresh green grasses and herbs. By summer, beginning in December, the herbs and grasses were dried to a yellow-brown and no longer useful for fresh food and water. Continuing in January and Febru-

TABLE 2

Seasonal summary of total time period (h) of population foraging activity of degus and the breakdown of that time according to exposure of the habitat to sun or shade. Data are derived from one continuous all-day count of activity per season

Resumen estacional del período de tiempo total (h) de la actividad de forrajeo poblacional de degus y los componentes de dicho tiempo de acuerdo a la exposición del hábitat al sol o sombra. Los datos provienen de observaciones puntuales de registro continuo de actividad realizadas durante un día en cada estación

\begin{tabular}{|c|c|c|c|c|}
\hline & Summer & Autumn & Winter & Spring \\
\hline \multicolumn{5}{|c|}{ Foraging Activitya } \\
\hline Morning & 2.5 & 2.7 & 5.8 & 4.6 \\
\hline Afternoon & 2.0 & 2.4 & - & 1.8 \\
\hline Total & 4.5 & 5.1 & 5.8 & 6.4 \\
\hline \multicolumn{5}{|c|}{ Exposure Sun/Shade } \\
\hline \multicolumn{5}{|l|}{ Morning } \\
\hline Shade & 1.3 & 0.3 & - & 0.1 \\
\hline Sun & 1.2 & 2.4 & 5.8 & 4.5 \\
\hline \multicolumn{5}{|l|}{ Afternoon } \\
\hline Sun & 1.0 & 2.3 & - & 1.8 \\
\hline Shade & 1.0 & 0.1 & - & - \\
\hline \multicolumn{5}{|l|}{ Total } \\
\hline Sun & 2.2 & 4.7 & 5.8 & 6.3 \\
\hline Shade & 2.3 & 0.4 & - & 0.1 \\
\hline
\end{tabular}

aPeriod of activity and intensive foraging for the population, from data of Fig. 1-4

${ }^{b}$ Shade refers to that amount of the activity period (a) that occurred prior to morning appearance of direct solar radiation (sun above skyline at the observation area) or following the afternoon disappearance of direct solar radiation. Sun refers to the period when direct solar radiation is impinging on the habitat (See Fig. 5.) 
ary, summer heat and aridity desiccated the environment further. April and May brought considerable precipitation in 1997. By late May and early June, as the degu mating season began, the environment started becoming green again, as the herbs and grasses forming the dietary staple of degus were restored. With a three-month gestation (Morales 1982), young were not born and lactation did not start until September. The new green vegetation continued growing into October, when the young emerged onto the surface.

The population spent as little as $4.5 \mathrm{~h}$ but no more than $6.4 \mathrm{~h}$ per day foraging (Table 2 ). These population values are an overestimate of foraging time for individuals, because individuals occasionally entered their burrows or rested on the surface without foraging. The shortest total daily foraging, $4.5 \mathrm{~h}$ in summer, occurred after the decline of green vegetation and post-weaning juvenile growth. The longest total daily foraging, $6.4 \mathrm{~h}$ in spring, occurred when females were lactating.

\section{DISCUSSION}

Our observations show that degus changed their daily activity pattern over the year in response to changes in day length and environmental heat load. Summer heat load in the open habitat was sufficiently stressful to prohibit activity over a midday gap of more than $8 \mathrm{~h}$. Despite the scarcity of shade (due to lack of shrubs and trees) these animals did not appear to shuttle regularly between surface and burrows. More than half the duration of the two daily activity bouts of summer activity occurred under early-morning and lateafternoon shade provided when the sun was below the local skyline. Behavioral mechanisms for avoiding heat stress thus assure that degus are not pressed to their physiological tolerance limits. This fundamental role of behavior in avoiding physiological stress has been articulated earlier by Bartholomew (1964). Autumn and spring activity of degus was also bimodal, but with shorter gaps between the two bouts. Winter activity was unimodal and occurred exclusively under direct solar radiation, which was less intense than at other seasons. Paradoxically, a cost of avoiding midday heat through development of a bimodal activity pattern is that degus in summer, autumn, and spring can be exposed to colder early morning thermal conditions on the surface than they are during winter unimodal activity.

Thermal ecology of small day-active mammals in hot, arid environments has been most thoroughly investigated in rodents of the squirrel family. The Piute ground squirrel, Spermophilus mollis, of North America's Great Basin Desert, ceases activity in open grassland during midday in summer; however, in sagebrush habitat they remain active all day (Sharpe \& Van Horne 1999). The antelope ground squirrel, Ammospermophilus leucurus, of North American deserts, remains active all day all year and has an extremely labile body temperature; when above ground it acquires excess heat, which it loses either while resting in the shade or by retiring into its burrow (Chappell \& Bartholomew 1981a, 1981b). The Cape ground squirrel of southern Africa, Xerus inauris, is also active all day, apparently has similar physiological capacities to antelope ground squirrels (Bennett et al. 1984, Van Heerden \& Dauth 1987), and both species use their tails to shade the body, in parasol-like fashion (Bennett et al. 1984).

Patterns of activity, heat load, and intermittent retreat into burrows ("shuttling") have been analyzed in ground squirrels (Ammospermophilus and Spermophilus), recognizing the lability of their body temperature. Our observations did not reveal shuttling of degus between surface and burrow. Such surface-to-burrow shuttling coupled with $\mathrm{T}_{\mathrm{b}}$ oscillations provides a theoretically appealing behavioral mechanism of thermoregulation (Hainsworth 1995). Although Chappell \& Bartholomew (1981a, 1981b) thoroughly documented short-term changes in $\mathrm{T}_{\mathrm{b}}$ of $A$. leucurus, they did not include simultaneous direct behavioral observation of retreat into the burrow to unload heat. Vispo \& Bakken (1993), studying $S$. tridecemlineatus, demonstrated an increase of time in the burrow as environmental temperature increased; they found a 10 -min cycle of $\mathrm{T}_{\mathrm{b}}$ with a 2 ${ }^{\circ} \mathrm{C}$ amplitude that accompanied bouts of shuttling.

The degu's seasonal shift of activity from bimodal to unimodal resembles the pattern in desert lizards (Porter et al. 1973, Huey et al. 1977). However, the physiological basis of the behavior is different. Degus, as endotherms, avoid extremes of environmental temperature and regulate $\mathrm{T}_{\mathrm{b}}$ narrowly (homeothermy). Lizards, as ectotherms, also avoid extremes, but select times and thermal conditions that allow daytime $\mathrm{T}_{\mathrm{b}}$ 's that fall within a broader acceptable range for optimizing behavioral performance. Desert beetles of the family Tenebrionidae, also ectotherms, shift activity seasonally between unimodal and bimodal and between day and night to achieve $\mathrm{T}_{\mathrm{b}}$ 's in a relatively narrow and cool range for optimizing behavioral performance (Kenagy \& Stevenson 1982).

How do habitat structure and thermal characteristics influence distribution of degu popula- 
tions? Our study indicates the importance of behavior in the success of degus in open habitat. We noted that in habitat adjoining our observation area degus were active in the shade of shrubs and trees when the degus in our open area were not above ground. The shade-producing advantages of shrub and tree cover for thermal protection of degus have been demonstrated by Lagos et al. (1995), who also suggested that such cover provides protection from predators.

In contrast to the use of cover for protection from predators, degus occupying open areas show a greater tendency to group together and devote more time to antipredatory vigilance (Vásquez 1997, Vásquez et al. 2002, Ebensperger \& Wallem in press). The timing of their activity also subjects degus, uniquely and precariously, to a variety of major types of predators that are active either diurnally, nocturnally, or both (Jaksic et al. 1981b). This challenge adds to the repertoire of behavioral mechanisms required for degus to avoid predation, and they are not able to dedicate themselves to a single activity window that promotes avoidance of predation (Clark \& Levy 1988).

Because no data are presently available on $T_{b}$ and tolerances of free-ranging degus, we are limited to laboratory data to interpret our field observations. Degus in the laboratory reduce time feeding if food is only available under a heat lamp (Torres-Contreras \& Bozinovic 1997). The degu thermal neutral zone ranges $24-32^{\circ} \mathrm{C}$ (Rosenmann 1977), which means that energy expenditure and water mobilization must be accelerated at $\mathrm{T}_{\text {air }}$ > $32{ }^{\circ} \mathrm{C}$ to avoid an increase in $\mathrm{T}_{\mathrm{b}}$. Average $\mathrm{T}_{\mathrm{b}}$ is $37.2^{\circ} \mathrm{C}$ (Rosenmann 1977) or $36.8^{\circ} \mathrm{C}$ (Refinetti 1996), depending on method of measurement, and the daily amplitude is about $2.6^{\circ} \mathrm{C}$, with range $36-38{ }^{\circ} \mathrm{C}$ (Refinetti 1996). Although a lethal $\mathrm{T}_{\mathrm{b}}$ of $42{ }^{\circ} \mathrm{C}$ is reported by Rosenmann (1977), obtained by forced exposure to high $\mathrm{T}_{\text {air }}$, we have no idea if degus allow $\mathrm{T}_{\mathrm{b}}$ to exceed $39^{\circ} \mathrm{C} \mathrm{C}$ under natural conditions. We conclude that excursions of $\mathrm{T}_{\mathrm{b}}$ above this range seem unlikely, given the conservative solar avoidance of degus. Degus are also energetically sensitive to temperatures below their lower critical temperature of 24 ${ }^{\circ} \mathrm{C}$. In winter degus avoided cold morning air by waiting to begin activity until $\mathrm{T}_{\mathrm{e}}$ was $>25^{\circ} \mathrm{C}$.

What are the limits of solar exposure for degus? Degu activity was generally curtailed as $\mathrm{T}_{\mathrm{e}}$ rose above $40^{\circ} \mathrm{C}$, and a $\mathrm{T}_{\mathrm{e}}$ of $50^{\circ} \mathrm{C}$ could certainly only be tolerated briefly. Vispo \& Bakken (1993), using different methods of measurement, report that Spermophilus tridecemlineatus were active at $\mathrm{T}_{\mathrm{e}}=30-40{ }^{\circ} \mathrm{C}$, and that activity was curtailed, as with degus, at $\mathrm{T}_{\mathrm{e}}>40{ }^{\circ} \mathrm{C}$. Walsberg (1992) analyzed structural properties of ground squirrel
(Spermophilus spp.) fur that provide protection from solar radiation, including outer coat coloration and depth and density of middle and outer layers of coat hair. It is important to determine whether solar protection provided by the coat of degus approaches that of sciurid rodents, which have a longer phylogenetic history of daytime activity.

Daytime activity is apparently recently derived in O. degus. Two other species of Octodon and the rest of the South American endemic family Octodontidae are all considered nocturnal (Contreras et al. 1987). Although most reports indicate O. degus is diurnal (Fulk 1976, Yáñez \& Jaksic 1978, Iriarte et al. 1989), possible contradiction was raised (Iriarte et al. 1989). Our explicit trapping design revealed a lack of nocturnal activity any time of year. We conclude that the recent derivation of day-time activity in $O$. degus may explain its strong behavioral avoidance and apparent physiological intolerance of midday thermal conditions during most of the year.

What are the consequences of seasonal shifts in foraging time for daily energy balance? What flexibility do degus have for shifting the timing of passage of ingested food through the gut? We have explored in the laboratory the time constraints for food processing by degus on their low-quality (high-fiber) diet (Kenagy et al. 1999). Despite experimental reduction in daily food availability to as little as $5 \mathrm{~h}$, as experienced in summer, degus maintained positive energy balance by regular reingestion of feces, i.e., coprophagy (Kenagy et al. 1999). Thus another behavioral mechanism adds to the flexibility of degus for responding to environmental variation.

\section{ACKNOWLEDGMENTS}

Support for this research was provided by the U.S. National Science foundation (INT 9600578) for cooperative research in Chile and by the Fondo de Desarrollo Cientifico (1950394) to G.J.K. and F.B. We thank George Bakken, Mark Chappell, Reid Hainsworth, Ray Huey, Kevin O'Brien, Swifty Stevenson, and Glenn Walsberg for advice on analysis and presentation. This paper is dedicated to the memory of Marie Gourley Kenagy, who encouraged this research.

\section{LITERATURE CITED}

BAKKEN GS (1992) Measurement and application of operative and standard operative temperatures in ecology. American Zoologist 32: 194-216. 
BAKKEN GS, PS REYNOLDS, KP KENOW, CE KORSCHGEN \& AF BOYSEN (1999) Standardization and calibration of heated mounts illustrated with day-old mallard ducklings. Physiological and Biochemical Zoology 72: 502-506.

BARTHOLOMEW GA (1964) The roles of physiology and behaviour in the maintenance of homeostasis in the desert environment. Symposium of the Society of Experimental Biology 18: 7-29.

BENNETT AF, RB HUEY, H JOHN-ALDER \& KA NAGY (1984) The parasol tail and thermoregulatory behavior of the cape ground squirrel, Xerus inauris. Physiological Zoology 57: 57-62.

CHAPPELL MA \& GA BARTHOLOMEW (1981a) Standard operative temperatures and thermal energetics of the antelope ground squirrel Ammospermophilus leucurus. Physiological Zoology 54: 81-93.

CHAPPELL MA \& GA BARTHOLOMEW (1981b) Activity and thermoregulation of the antelope ground squirrel Ammospermophilus leucurus in winter and summer. Physiological Zoology 54: 215-223.

CLARK CW \& DA LEVY (1988) Diel vertical migrations by juvenile sockeye salmon and the antipredation window. American Naturalist 131: 271-290.

CLARK CW \& M MANGEL (2000) Dynamic state variable models in ecology: methods and applications. Oxford University Press, New York, New York. 289 pp.

CONTRERAS LC, JC TORRES-MURA \& JL YÁÑEZ (1987) Biogeography of octodontid rodents: an ecoevolutionary hypothesis. Fieldiana Zoology, New Series 39: 401-411.

CORTÉS A, M ROSENMANN \& C BÁEZ (1990) Función del riñon y del pasaje nasal en la conservación de agua corporal en roedores simpátridos de Chile central. Revista Chilena de Historia Natural 63: 279-291.

CUTHILL IC \& AI HOUSTON (1997) Managing time and energy. In: Krebs JR \& NB Davies (eds) Behavioural ecology: an evolutionary approach: 97-120. Fourth edition. Blackwell Science, Oxford, United Kingdom.

EBENSPERGER LA \& PK WALLEM (in press) Grouping increases the ability of the social rodent, Octodon degus, to detect predators when using exposed microhabitats. Oikos.

FULK GW (1976) Notes on the activity, reproduction, and social behavior of Octodon degus. Journal of Mammalogy 57: 495-505.

GATES DM (1980) Biophysical ecology. Springer-Verlag, Berlin, Germany. $611 \mathrm{pp}$.

HAINSWORTH FR (1995) Optimal body temperatures with shuttling: desert antelope ground squirrels. Animal Behaviour 49: 107-116.

HOUSTON AI \& JM MCNAMARA (1999) Models of adaptive behaviour: an approach based on state. Cambridge University Press, Cambridge, United Kingdom. 378 pp.

HUEY RB (1991) Physiological consequences of habitat selection. American Naturalist, Supplement 137: 91 115.

HUEY RB, ER PIANKA \& JA HOFFMAN (1977) Seasonal variation in thermoregulatory behavior and body temperature of diurnal Kalahari lizards. Ecology 58: 1066-1075.
IRIARTE JA, LC CONTRERAS \& FM JAKSIC (1989) A long-term study of a small-mammal assemblage in the central Chilean matorral. Journal of Mammalogy 70: 79-87.

JAKSIC FM, JL YÁÑEZ \& ER FUENTES (1981a) Assessing a small mammal community in central Chile. Journal of Mammalogy 62: 391-396.

JAKSIC FM, HW GREENE \& JL YÁÑEZ (1981b) The guild structure of a community of predatory vertebrates in central Chile. Oecologia 49: 21-28.

KENAGY GJ (1976) The periodicity of daily activity and its seasonal changes in free-ranging and captive kangaroo rats. Oecologia 24: 105-140.

KENAGY GJ \& RD STEVENSON (1982) Role of body temperature in the seasonality of daily activity in tenebrionid beetles of eastern Washington. Ecology 63: 1491-1503.

KENAGY GJ, C VELOSO \& F BOZINOVIC (1999) Daily rhythms of food intake and feces reingestion in the degu, an herbivorous Chilean rodent: optimizing digestion through coprophagy. Physiological and Biochemical Zoology 72: 78-86.

KENAGY GJ, RA VÁSQUEZ, RF NESPOLO \& F BOZINOVIC (2002) A time-energy analysis of daytime surface activity in degus, Octodon degus. Revista Chilena de Historia Natural 75: 149-156.

KREBS JR \& A KACELNIK (1991) Decision-making. In: Krebs JR \& NB Davies (eds) Behavioural ecology: an evolutionary approach: 105-136. Third edition. Blackwell Science, Oxford, United Kingdom.

LAGOS VO, F BOZINOVIC \& LC CONTRERAS (1995) Microhabitat use by a small diurnal rodent (Octodon degus) in a semiarid environment: thermoregulatory constraints or predation risk? Journal of Mammalogy 76: 900-905.

LE BOULENGÉ E \& ER FUENTES (1978) Quelques donneés sur la dynamique de population chez Octodon degus (rongeur Hystricomorphe) du Chili central. La Terre et la Vie 32: 325-341.

MESERVE PL, R MARTIN \& J RODRÍGUEZ (1984) Comparative ecology of the caviomorph rodent Octodon degus in two Chilean mediterranean-type communities. Revista Chilena de Historia Natural 57: 79-89.

MOLINA GI (1782) Saggio sulla storia naturale del Chili. Tommaso d'Aquino, Bologna, Italy. 367 pp.

MORALES B (1982) Estado de avance en el estudio de la reproducción y embriología de un mamífero chileno. Museo Nacional de Historia Natural, Publicación Ocasional (Chile) 38: 145-164.

PORTER WP, JW MITCHELL, WA BECKMAN \& CB DEWITT (1973) Behavioral implications of mechanistic ecology - thermal and behavioral modeling of desert ectotherms and their microenvironment. Oecologia 13: 1-54.

REFINETTI R (1996) Comparison of the body temperature rhythms of diurnal and nocturnal rodents. Journal of Experimental Zoology 275: 67-70.

ROSENMANN M (1977) Regulación térmica en Octodon degus. Medio Ambiente (Chile) 3: 127-131.

RUNDEL PW (1981) The matorral zone of central Chile. In: DI CASTRI F, DW GOODALL \& RL SPECHT (eds) Mediterranean type shrublands: 175-201. Elsevier, Amsterdam, The Netherlands. 
SHARPE PB \& B VAN HORNE (1999) Relationships between the thermal environment and activity of Piute ground squirrels (Spermophilus mollis). Journal of Thermal Biology 24: 265-278.

TORRES-CONTRERAS H \& F BOZINOVIC (1997) Food selection in an herbivorous rodent: balancing nutrition with thermoregulation. Ecology 78: 2230-2237.

VAN HEERDEN J.\& J DAUTH (1987) Aspects of adaptation to an arid environment in free-living squirrels Xerus inauris. Journal of Arid Environments 13: 8389.

VÁSQUEZ RA (1997) Vigilance and social foraging in Octodon degus (Rodentia: Octodontidae) in central Chile. Revista Chilena de Historia Natural 70: 557 563.

Invited Editor: L. Ebensperger

Received February 20, 2002; accepted June 17, 2002
VÁSQUEZ RA, LA EBENSPERGER \& F BOZINOVIC (2002) The influence of habitat on travel speed, intermittent locomotion, and vigilance in a diurnal rodent. Behavioral Ecology 13: 12-187.

VISPO CR \& GS BAKKEN (1993) The influence of thermal conditions on the surface activity of thirteenlined ground squirrels. Ecology 74: 377-389.

WALSBERG GE (1992) Quantifying radiative heat gain in animals. American Zoologist 32: 217-224.

WALSBERG GE \& BO WOLF (1996) An appraisal of operative temperature mounts as tools for studies of ecological energetics. Physiological Zoology 69: 658681.

YÁÑEZ J \& F JAKSIC (1978) Historia natural de Octodon degus (Molina) (Rodentia, Octodontidae). Museo Nacional de Historia Natural, Publicación Ocasional (Chile) 27: 3-11. 